\title{
Are corridors good for tigers Panthera tigris but bad for people? An assessment of the Khata corridor in lowland Nepal
}

\author{
Per Wegge, Shailendra Kumar Yadav and Babu Ram Lamichiane
}

\begin{abstract}
As part of a landscape-scale programme for conserving tigers Panthera tigris the Khata corridor was established between Bardia National Park in Nepal and Katarniaghat Wildlife Sanctuary in India in early 2000. We examined its functionality by comparing the status of tigers and prey in the corridor and in the adjacent National Park, using camera trapping, transect sampling and diet analysis of scats. Tiger movement was inferred from the photographs, and tiger-human conflict was assessed by means of questionnaires and interviews. The corridor harboured transient individuals as well as resident, breeding tigers. Tigers with core areas in the corridor were also recorded in the two protected areas, and vice versa. Wild prey was 3-4 times more abundant in the area of the National Park bordering the corridor than in the corridor itself, and domestic livestock constituted $12-15 \%$ of the tigers' food in the corridor. Livestock losses and human fatalities or injuries were relatively low compared to within the buffer zones of the National Parks. Despite such problems and restrictions on grazing and extraction of natural resources, local residents were generally positive towards tigers and the corridor. The successful establishment of the corridor and the positive attitudes of local people were attributable to community development programmes initiated to compensate for the imposed restrictions, financed by the government and national and international organizations. By linking Bardia National Park and Katarniaghat Wildlife Sanctuary via the Khata corridor, a protected tiger landscape of c. $3,000 \mathrm{~km}^{2}$ was established in west-central Nepal and northern India.
\end{abstract}

Keywords Carnivores, Nepal, Panthera tigris, tiger, wildlife conflict, wildlife corridor

This paper contains supplementary material that can be found online at https://doi.org/10.1017/So03060531600o661

Per WegGe (Corresponding author) Department of Ecology and Natural Resource Management, Norwegian University of Life Sciences, Ås, Norway E-mail per.wegge@nmbu.no

Shailendra Kumar Yadav Bardia Conservation Program, National Trust for Nature Conservation, Thakurdwara, Nepal

Babu Ram Lamichnane Biodiversity Conservation Centre, National Trust for Nature Conservation, Sauraha, Nepal

Received 7 May 2016. Revision requested 31 May 2016.

Accepted 22 June 2016. First published online 28 October 2016.

\section{Introduction}

$W^{\text {ith the ongoing fragmentation of landscapes, wildlife }}$ populations are becoming increasingly isolated, making them vulnerable to inbreeding depression and loss of viability as a result of stochastic demographic events. This is particularly true for large carnivores and herbivores, which require a large area. The Endangered tiger Panthera tigris is such a species; numbers had declined to c. 3,200 adults by 2010 (GTRP, 2010) as a result of loss and fragmentation of habitat (Wikamanayake et al., 1998), reduction of prey base (Karanth \& Stith, 1999), poaching (Nowell \& Jackson, 1996) and conflict with people (Gurung et al., 2008). It has been inferred that small tiger populations are vulnerable to extinction because of their highly structured genetic compositions (Kenney et al., 2014).

Following the realization in the 1990 os that tigers exist in more or less isolated subpopulations, the conservation strategy for tigers and other threatened large mammals has expanded from traditional protected area management to a metapopulation approach focused on providing connectivity between neighbouring populations (Wikramanayake et al., 1998). Although the scientific basis for this approach has been questioned (Simberloff et al., 1992), landscape management has become a main focus of tiger conservation work. Several large-scale studies have been conducted in India (Harihar \& Pandav, 2012; Rathore et al., 2012; Joshi et al., 2013; Sharma et al., 2013a; Athreya et al., 2014; Yumnam et al., 2014), mostly examining the extent of movement and gene flow between isolated populations. The results disclosed higher genetic connectivity (thus more movement among fragments) than anticipated, and dispersal was found to occur across $>100 \mathrm{~km}$ of degraded habitat without resident tigers, connectivity presumably being facilitated by remnant strips of forest corridors within the human-dominated landscape (Sharma et al., 2013b).

Nepal has initiated several conservation programmes to protect tigers, culminating in the creation of the Terai Arc Landscape Programme between India and Nepal (Chanchani et al., 2014), which aims to increase the land base for tigers (Smith et al., 1998) and to restore connectivity between protected areas (Wikramanayake et al., 2004). In Nepal there is no legal provision for a wildlife corridor as a separate entity. Thus, using the existing provision of protected forest, in 2010 the government declared the identified potential tiger corridors as protection forests, thereby providing some legal provision for their protection. Based on 
an intensive survey in 2013 the total number of adult tigers in the country was estimated to be 163-235 (Dhakal et al., 2014).

Conserving large carnivores is problematic not only because of human-induced habitat fragmentation and potential loss of genetic viability; they pose a threat to people's safety and cause economic loss to farmers as a result of depredation of livestock, thus leading to conflicts with local communities (Saberwal et al., 1994; Treves \& Karanth, 2003; Woodroffe et al., 2005; Inskip \& Zimmermann, 2009; Goodrich, 2010). Nepal has set aside tracts of fertile land as protected areas and has expanded these with buffer zones, thus restricting local people's access to natural resources. Creating corridors as an additional conservation measure has therefore been met with opposition, both locally and among some government officials: there is a saying that 'establishing corridors may be good for tigers but bad for people'. When establishing wildlife corridors a main challenge is therefore to minimize conflict with local people (Dinerstein et al., 2006). To our knowledge no study had previously examined the functionality of corridors for tigers and simultaneously assessed the level of conflict that such a conservation measure creates for local people. We assessed the condition of the Khata corridor between Bardia National Park in Nepal and Katarniaghat Wildlife Sanctuary in India by comparing tiger abundance, prey base and diets in the corridor and in the adjoining part of the park, and assessing the movement of tigers between the two protected areas via the corridor. We also examined tiger-human interactions by assessing the perceptions and attitudes of local people towards tigers and the conservation activities being implemented in the corridor.

\section{Study area}

The western part of Bardia National Park is known to support relatively dense populations of tigers and ungulate prey species (Wegge et al., 2009; Dhakal et al., 2014). The southern end of this part of the park extends into Khata, an area consisting of degraded forest interspersed with agricultural settlements, between the border of the park and the Katarniaghat Wildlife Sanctuary (Fig. 1). The study was carried out in the Khata corridor (c. $90 \mathrm{~km}^{2}$ ) and the adjoining south-west corner of the park (c. $60 \mathrm{~km}^{2}$ ). Until 6-7 decades ago the whole area consisted of contiguous pristine forests and grasslands along the Geruwa river, inhabited only by a small number of indigenous, malaria-resistant Tharu people. Especially rich in wildlife, the area now referred to as the south-west corner was then protected as a Royal Hunting Reserve. With the eradication of malaria in the 1950 s and the subsequent government programme of resettling hill people to the lowlands, many people immigrated, settled and cleared land for cultivation. In what is now the Khata corridor the increasing pressure from hunting and snaring of wildlife, cutting of timber and fuelwood, and grazing of livestock reduced the populations of ungulates and large predators, thereby diminishing or cutting off the movement of tigers and other large mammals between the protected areas on each side of the national border (Bolton, 1976).

The corridor is more or less rectangular in shape, c. 11-12 $\mathrm{km}$ long and $8 \mathrm{~km}$ wide. It consists of degraded buffer zone and community forest $\left(65 \mathrm{~km}^{2}\right)$, some of it converted to open scrub forest as a result of excessive tree felling and livestock grazing. The remaining $25 \mathrm{~km}^{2}$ consists of four settlements with 170 households (c. 1,00o people), surrounded by cultivated land. The households within and along the border of the corridor kept c. 7,000 livestock (this study). Slightly more than one third of these were being grazed in the corridor, consisting of c. 1,00o large stock, mainly cattle, and c. 1,300 small stock. Nearly all cattle were accompanied by a watcher but some unproductive cows were left to graze unattended. Management and conservation activities are directed and implemented jointly by Bardia National Park/ Department of National Parks and Wildlife Conservation, the District Forest Office/Department of Forest, and the National Trust for Nature Conservation (Nepal). A separate body, the Khata Corridor Coordination Committee, oversees human-wildlife conflict and compensation schemes.

The first step towards establishing a wildlife corridor between Bardia National Park and Katarniaghat Wildlife Sanctuary was taken in 1996 when a 2-4 km wide buffer zone was established around the park. During the following years a series of local community development activities were initiated and regulations regarding human activities and extraction of natural resources were adopted and implemented. Lacking a legal classification for wildlife corridors, in 2010 the government designated the whole area between the south-western border of the park and the Katarniaghat Wildlife Sanctuary at the Indian border as a protected forest. Since then, other regulations and management interventions have been added and successively implemented. The Nepalese government and national and international NGOs have promoted and funded these activities.

The south-west corner of Bardia National Park is bordered by agricultural settlements in the west and east and is contiguous with the National Park in the north and the Khata corridor in the south. Where the park connects with the corridor in the south it is only a few $\mathrm{km}$ wide; in the north, the south-west corner is wider as it merges with the larger National Park. The Geruwa river forms the western boundary of both study areas (Fig. 1). Biophysical, faunal and botanical descriptions of the south-west corner are provided in Dinerstein (1979) and Wegge et al. (2009). In the park the floodplain along the Geruwa river consists of a mosaic of forest types and tall and short grasslands. Originally the corridor had similar vegetation and associated fauna; however, as a result of land clearing and human settlements since the 1950 most of the forests and scrubby grasslands 


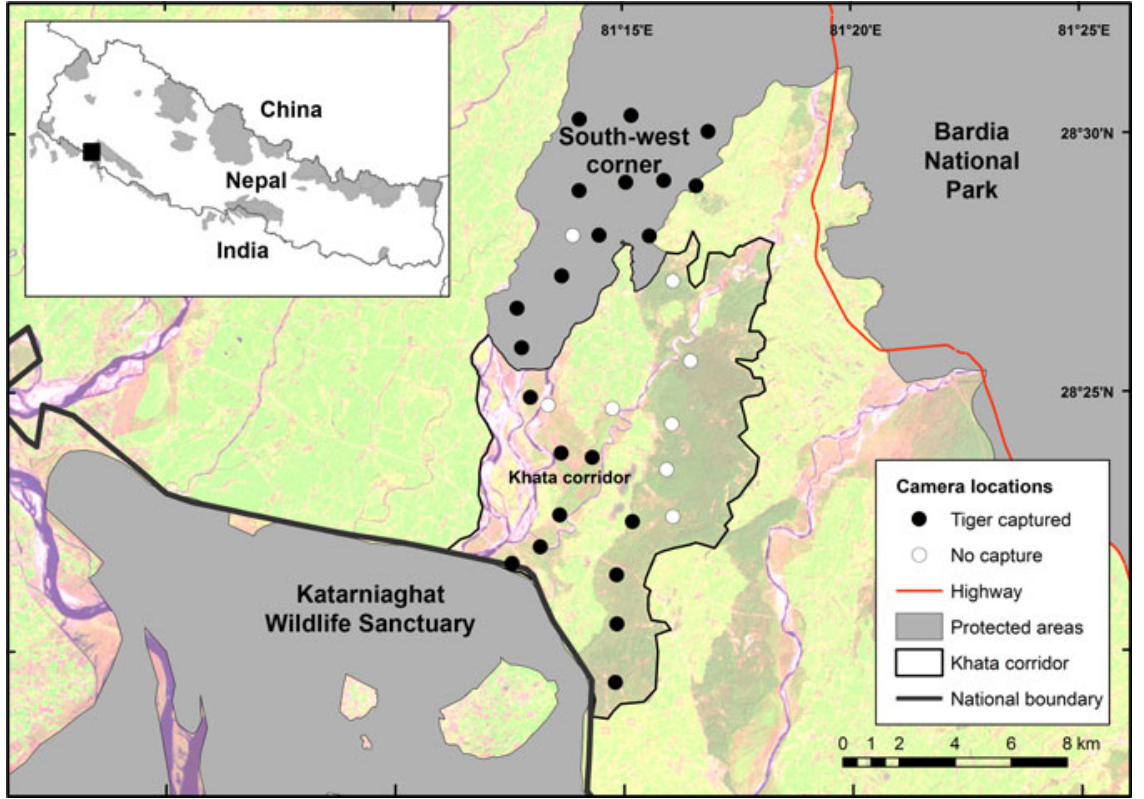

Fig. 1 Locations of camera trapping stations in the south-west corner of Bardia National Park and in the Khata corridor, in Nepal, bordering Katarniaghat Wildlife Sanctuary in India. In the corridor and outside the protected areas light shading indicates agricultural settlements, and darker shading indicates forested areas. have become degraded and the wildlife has been depleted (Jnawali, 1995).

India's Katarniaghat Wildlife Sanctuary, which is connected to the Khata corridor along a 5-6 km strip at its northwestern corner, covers c. $400 \mathrm{~km}^{2}$ and sustains $17-24$ tigers (Chanchani et al., 2014). Like the corridor, the sanctuary is surrounded by agricultural settlements on all sides except for the narrow strip that connects it to the corridor (Fig. 1).

\section{Methods}

The study included local capacity building in cooperation with local stakeholders and was carried out in compliance with the ethical code of conduct of the British Sociological Association.

\section{Tiger abundance}

During 2012 and 2013 we used camera trapping to estimate the numbers and densities of tigers in the corridor and in the south-west corner of Bardia National Park. We divided the areas into $2 \times 2 \mathrm{~km}^{2}$ grid cells and within each we fixed one pair of digital cameras along a trail or road that was frequently used by tigers (Karanth, 1995). We deployed 30 pairs of cameras in total, 17 in Khata and 13 in the south-west corner of the park, and carried out the sampling concurrently in both areas, with 15 continuous trapping nights per station. Camera trapping has also been carried out in the Katarniaghat Wildlife Sanctuary, by the Uttar Pradesh Forest Department and WWF-India. A report on tigers in the Transboundary Terai Arc Landscape (Chanchani et al., 2014) included photographs of tigers in the sanctuary, which facilitated identification of individuals that had also been trapped in the corridor.
We analysed the capture data by various methods. Firstly, we calculated indices of abundance from the number of captures per 100 camera trap nights (Carbone et al., 2001). The number of tigers in the two adjacent study sites at the time of sampling was estimated from capture-recapture analyses, using CAPTURE (White et al., 1978). Earlier experimental camera trapping in the park had shown that a spacing of $<2 \mathrm{~km}$ between stations combined with a trapping duration of $\geq 10$ days per station should capture all tigers present within the trapping grid (Wegge et al., 2004). We therefore assume that we captured all individuals that were present within the study areas at the time of sampling. Thus, the number of tigers photographed by camera traps should be similar to the results generated by the CAPTURE model. As sampling in each area was completed in one sweep within 15 days, the statistical requirement for spatial population closure was fulfilled (Otis et al., 1978; Karanth \& Nichols, 1998).

As both study areas are small they are not suitable for estimating separate population densities reliably. Instead, we combined the capture data and estimated density for the combined area of c. $150 \mathrm{~km}^{2}$. For this we applied the Bayesian spatially explicit capture-recapture model in SPACECAP 1.1.o (Gopalaswamy et al., 2012), implemented in $R$ v. 3.0.1 (R Development Core Team, 2013). With a Bayesian framework SPACECAP combines the distribution of activity centres of sampled individuals and spatial detection functions to estimate density (Royle et al., 2009). We only used data from 2013 for the density estimation.

\section{Prey abundance}

To estimate prey densities we used Distance sampling along line transects (Buckland et al., 2001; Thomas et al., 2010), 
and recorded animal numbers from elephant back, as recommended for habitats in Bardia National Park (Wegge \& Storaas, 2009). From a random starting point we surveyed 55 transects in total (17 along $57 \mathrm{~km}$ in the south-west corner of Bardia National Park and 38 along $75 \mathrm{~km}$ in Khata), spaced $500 \mathrm{~m}$ apart, in February 2013. We analysed the data using DISTANCE 6.o (Thomas et al., 2009). For several species the sample sizes were too small to generate meaningful density estimates for each area separately. We therefore also calculated abundance indices by enumerating the number of individuals of each species observed along $10 \mathrm{~km}$ transect segments in each of the two study areas.

\section{Tiger diet}

Tiger diets were estimated from micro-histological analysis of scats collected during the dry and wet seasons of 2013. Scats were collected opportunistically along forest roads and trails known to be used frequently by tigers. Tiger scats were distinguished from those of leopards Panthera pardus based on their appearance and associated pug-marks and scrapes; scats of tigers are larger, with a lower degree of coiling and relatively larger distance between two successive constrictions within a single piece of scat (Mukherjee et al., 1994; Biswas \& Sankar, 2002). Ideally the scats would have been verified to species through genetic analysis, as we may have inadvertently included scats from leopards (Farrell et al., 2000). However, as questionable scats were discarded and the density of leopards was 3-4 times lower than that of tigers, with extensive interspecific dietary overlap (Wegge et al., 2009), we believe errors were minimal. For analysis we used the point-frame method (Ciucci et al., 2004), as it adjusts for rare prey items in the frequency calculations. Instead of using drop pins to select the prey items, we selected the prey items at each intersection $(n=50)$ in a gridded tray with a pair of tweezers and examined these under a dissecting microscope, or a high-power microscope if needed for reliable identification (Wegge et al., 2012). We prepared reference slides of potential prey species occurring in the area. We determined the diet by analysing the content of 127 tiger scats collected over a period of 16 months: 59 and 26 scats collected from the south-west corner of the park in winter and summer, respectively, and 34 and 8 scats collected from the Khata corridor in winter and summer, respectively.

We adjusted the relative proportions of prey species (numbers and biomass) in the diet according to prey size, using an equation derived from experimental work on the cougar Felis concolor (Ackerman et al., 1984):

$$
\mathrm{Y}=1.980+0.035 \mathrm{X}
$$

where $Y$ is the weight of prey consumed per scat and $X$ is the prey body weight $(\mathrm{kg})$.

The main purpose of the scat analysis was to compare the diet in the two study areas. As few scats were collected during the monsoon we restricted the comparison to the dry season. Hence, the frequency distributions of prey species in the scat samples collected during the monsoon were used mainly as crude, supplementary information.

We estimated selection of prey species by comparing the proportions of each prey type in the scats, after adjusting for prey size, with the expected proportions derived from the Distance sampling. For this, we used SCATMAN (Link \& Karanth, 1994). From the specified frequency observations of the various prey items in the scats and the means and standard deviations of the prey density estimates, this software estimates the relative number of scats produced per kill and compares observed and expected proportions of prey species by using likelihood ratio tests (G-tests; Zar, 1984), based on a parametric bootstrapping procedure. Pooling samples from the two areas and seasons, we performed 1,00o bootstrap iterations; when two prey species were detected in a scat we counted each as 0.5 (Karanth \& Sunquist, 1995).

\section{Tiger-human conflict}

Tiger-human conflict was previously investigated along the entire border of Bardia National Park (Bhattarai \& Fischer, 2014). To supplement that study with a focus on the conflict situation and people's perceptions along and within the Khata corridor, we collected information by means of a selfadministered questionnaire survey distributed among 170 randomly selected households in the villages within and along the periphery of the corridor. The questionnaires followed the design of Gurung et al. (2008) and consisted of closed-ended questions with multiple, optional answers (Supplementary Material S1). To gather more specific information about encounters of people and livestock with tigers we also carried out semi-structured interviews with 61 households that had experienced such encounters. In addition, we interviewed 20 chairpersons of Community Forest User Groups, 17 nature guides, five protected area managers and seven elephant caretakers, mainly enquiring about their general perceptions and attitudes. From the park headquarters and the field station of the National Trust for Nature Conservation we obtained information on the history and implementation of various community development programmes and conservation measures in the Khata corridor since 1996 (Supplementary Table S1).

\section{Results}

\section{Abundance and density of tigers}

The camera-trapped tigers were distributed across most of the two sampling areas (Fig. 1). In the south-west corner of Bardia National Park $\left(60 \mathrm{~km}^{2}\right)$ the mean number of 
TABLE 1 Indices of tiger Panthera tigris abundance in the south-west corner of Bardia National Park and the Khata corridor (Fig. 1) during 2012 and 2013 .

\begin{tabular}{|c|c|c|c|c|c|c|}
\hline \multirow[b]{2}{*}{ Parameters } & \multicolumn{3}{|c|}{$\begin{array}{l}\text { South-west corner of Bardia } \\
\text { National Park }\end{array}$} & \multicolumn{3}{|c|}{ Khata corridor } \\
\hline & 2012 & 2013 & Mean & 2012 & 2013 & Mean \\
\hline Number of individual tigers recorded by camera trap & 6 & 13 & 9.5 & 7 & 4 & 5.5 \\
\hline Number estimated by CAPTURE & & $15 \pm$ SE 4.4 & & & $4 \pm$ SE 0.2 & \\
\hline Number captured per 100 trap nights & 24.5 & 30.3 & 27.4 & 7.5 & 9.0 & 8.3 \\
\hline Number of days per tiger capture & 4.1 & 3.3 & 3.7 & 13.3 & 11.1 & 12.2 \\
\hline
\end{tabular}

TABLE 2 Numbers and IDs of individual tigers (F, female; M, male) camera-trapped in the south-west corner of Bardia National Park and in the Khata corridor (Fig. 1) during 2012 and 2013, with IDs of tigers captured in Katarniaghat Wildlife Sanctuary. Recaptured individuals from previous years are indicated in bold.

\begin{tabular}{|c|c|c|c|c|c|}
\hline \multirow[b]{2}{*}{ Year } & \multicolumn{2}{|c|}{ South-west Bardia National Park } & \multicolumn{2}{|c|}{ Khata corridor } & \multirow{2}{*}{$\frac{\text { Katarniaghat Wildlife Sanctuary }}{{ }^{1}}$} \\
\hline & No. & ID of individuals & No. & ID of individuals & \\
\hline 2012 & 6 & $\mathrm{~F}^{2}, \mathrm{~F}^{2}, \mathrm{~F} 7, \mathrm{M} 5, \mathrm{M} 6, \mathrm{M} 7$ & 7 & $\mathrm{~F} 1, \mathrm{~F} 2, \mathrm{~F} 3, \mathrm{~F} 4^{2}, \mathrm{~F}^{2}, \mathrm{M}^{3}{ }^{3}, \mathrm{M} 2^{3}$ & $\mathrm{M} 1^{3}, \mathrm{M} 2^{3}$ \\
\hline 2013 & 13 & $\begin{array}{l}\text { F4, F5, F6, F7, F8, F9, F10, F11, F12, M32 } \\
\text { M5, M6, M7 }\end{array}$ & 4 & $\mathrm{~F} 2, \mathrm{M} 2, \mathrm{M} 3^{2}, \mathrm{M}^{3}$ & $\mathrm{M} 4^{3}, \mathbf{F} 1$ \\
\hline
\end{tabular}

${ }^{1}$ Data from Chanchani et al. (2014)

${ }^{2}$ Captured in both the south-west corner of Bardia National Park and the Khata corridor in the same year

${ }^{3}$ Captured in both the Khata corridor and Katarniaghat Wildlife Sanctuary in the same year

individuals recorded in 2012 and 2013 was 9.5 (Table 1). The corresponding number for the Khata corridor $\left(90 \mathrm{~km}^{2}\right.$, with $65 \mathrm{~km}^{2}$ of tiger habitat) was 5.5. During the 2 years the mean frequency of tiger capture was 27.4 detections per 100 trap nights in the south-west corner of the park and 8.3 detections per 100 trap nights in the corridor. Most individuals were trapped three or more times, and some as many as 12 times. Using CAPTURE we estimated there were $15.0 \pm \mathrm{SE}$ 4.4 tigers in the south-west corner of the park and $4.0 \pm$ SE 0.2 in the Khata corridor, which are comparable to the numbers recorded by camera traps (Table 1 ).

To estimate tiger density across both study areas combined, SPACECAP selected the half-normal detection function with a Bayesian P-value of individual encounters of 0.684 . Density was estimated to be $7.0 \pm S D 1.0$ per $100 \mathrm{~km}^{2}$. The abundance estimate $\left(N_{\text {Super }}\right)$ of $22 \pm S D 3.24$ individuals was slightly higher than the sum of the separate estimates for the two study areas obtained using CAPTURE (19 \pm SE 4.6; Table 1).

\section{Distribution and movement of tigers}

During 2012 and 2013, 13 individual tigers were recorded in the south-west corner of the park, and nine in the Khata corridor (Table 2). Nineteen of these tigers were different individuals, seven males and 12 females.

Of the nine tigers recorded in the corridor, three were also recorded in the south-west corner of the park and four were also recorded in Katarniaghat Wildlife Sanctuary. Only two females $\left(\mathrm{F}_{2}\right.$ and $\left.\mathrm{F}_{3}\right)$ were captured exclusively in the corridor.
Among the four Khata tigers recorded in the wildlife sanctuary, one of the males $\left(\mathrm{M}_{2}\right)$ was the offspring of tigress $\mathrm{F}_{2}$. Two months after being recorded together with his mother he was captured in the wildlife sanctuary. His sister $\left(\mathrm{F}_{3}\right)$ dispersed a short distance and established a territory close to her mother within the corridor, near the border with the wildlife sanctuary.

\section{Composition and breeding}

Nine of the 13 tigers in the south-west corner of the park were female and four were male. In the Khata corridor there were four females and five males. During 2012-2013 the number of males increased slightly in both areas; meanwhile the number of females decreased in Khata but increased in the southwest corner of the park. However, changes between areas and years were not significant (Fisher's exact test, $P>0.29$ ).

In 2012 successful breeding was recorded in the corridor. The male offspring (M2) dispersed to Katarniaghat Wildlife Sanctuary and appeared to have established a territory, which included the southern part of the corridor. His sister $\left(\mathrm{F}_{3}\right)$ dispersed a short distance towards the wildlife sanctuary, where she probably settled. Another Khata tigress ( $\mathrm{F} 1$ ) bred in late 2013/early 2014, and an aborted foetus was subsequently found within her core area.

\section{Prey abundance}

In the south-west corner of the park 16.8 wild prey individuals were recorded per $\mathrm{km}$ of transect. In the Khata 


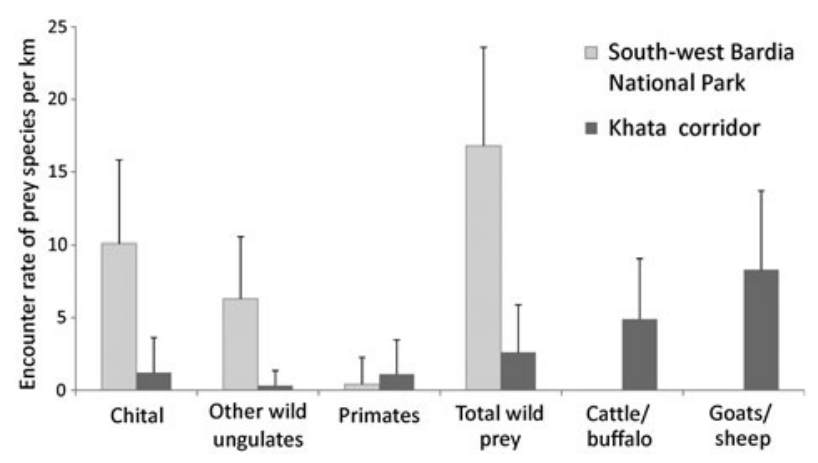

FIG. 2 Abundance of wild prey species and livestock (mean \pm SD) in the south-west corner of Bardia National Park and the Khata corridor in 2013.

corridor the corresponding frequency was $2.6 \mathrm{~km}^{-1}$ (Fig. 2). Seven wild prey species were recorded in the south-west corner of the park, and five in the corridor. The chital Axis axis was the most abundant species in both areas, with significantly higher abundance in the park (Mann-Whitney, $\mathrm{P}<0.02)$. Three other important prey species of the tiger, namely the hog deer Axis porcinus, sambar Rusa unicolor and swamp deer Rucervus duvaucelii, were not recorded in the corridor, only in the park. Primates were observed more frequently in the corridor but the difference was not significant (Mann-Whitney, $\mathrm{P}<0.22$ ). Even considering all species except the chital, more wild prey were recorded in the south-west corner of the park $(t=2.45, \mathrm{df}=8$, $\mathrm{P}=0.040$ ). In the corridor, livestock were more abundant than wild prey; however, total prey abundance (livestock and wild prey combined) was similar in the two areas (Fig. 2).

In the south-west corner of the park the chital had the highest density $\left(74.8 \pm \mathrm{SE} 14.8 \mathrm{~km}^{-2}\right)$, followed by the hog deer $\left(16.5 \pm \mathrm{SE} 6.4 \mathrm{~km}^{-2}\right)$. In the corridor only the chital was recorded in sufficient numbers for density estimation (18.1 \pm SE $11.5 \mathrm{~km}^{-2}$ ). Combining all species, the density of wild prey species was more than twice as high in the south-west corner of the park $\left(98.7 \pm \mathrm{SE} 13.3 \mathrm{~km}^{-2}\right)$ than in the corridor.

\section{Tiger diet}

Based on the frequency of occurrence in scats, the chital was the most important prey species in both areas, both in winter and summer (Table 3 ). Large wild ungulates were recorded only in the south-west corner of the park. During the dry season cattle were recorded more frequently in scats collected in the Khata corridor (Fisher's exact test, $\chi^{2}=0.008, \mathrm{P}<0.01$ ) and all wild prey species combined were recorded more frequently in the south-west corner of the park (Fisher's exact test, $\left.\chi^{2}=0.007, \mathrm{P}<0.01\right)$. There were no statistical differences $(\mathrm{P}>0.16)$ between any of the other species or groups. The small samples from the monsoon season were similar to the winter composition, especially with respect to the main food species.
Estimated prey biomass yielded a better assessment of the contribution of the various prey species in the diet. The chital was the single most important species, contributing $57.3 \%$ of the total biomass in the two study areas combined (Table 4). The chital was followed by the hog deer and the swamp deer, with relative biomass of 9.3 and $8.7 \%$, respectively. Nearly $8 \%$ of the biomass consisted of cattle. As cattle were depredated only in the corridor, large livestock probably comprised $12-15 \%$ of the diet there, considering their absence in the south-west corner of the park and fewer scat samples from the Khata corridor in the combined analysis. In the combined study area, sambar, swamp deer, wild boar Sus scrofa and barking deer Muntiacus muntjak were preyed upon significantly more often and chital significantly less than expected from their availabilities (Table 5).

\section{Tiger-human conflict and local people's perceptions}

During 1993-2013 three people were killed and four injured by tiger attacks in the corridor (i.e. a mean of 0.15 fatalities per year). Livestock losses have declined, particularly since 2007 (Fig. 3). During 2000-2007 the mean number of livestock killed annually was 19.1; in the following 6 years the mean annual loss was 6.3 animals $(t=4.103, \mathrm{df}=12, \mathrm{P}<0.001)$. Hence, annual losses of livestock as a result of predation by tigers declined from c. $1 \%$ to $<0.3 \%$ after 2007 .

For various reasons $68 \%$ of the respondents had positive attitudes towards tigers and tiger conservation (Table 6). Loss of livestock and attacks on people were the main reasons for negative attitudes. However, $44 \%$ of the respondents supported tiger conservation even if a family member had been killed or injured in a tiger attack. Similarly, $67 \%$ were supportive even if their livestock had been killed by a tiger or leopard. Regarding the management of problem tigers, the majority wanted them to be captured and killed or put in zoos. Others called for conservation education, an improved compensation process and monitoring of problem tigers. Trade of body parts and retaliation for livestock losses were the main reasons for tigers being killed. The dearth of wild prey in the corridor was the main reason given for the killing of livestock by tigers.

\section{Discussion}

With both resident and transient tigers, the corridor was biologically functional. The overall positive attitude of local residents disproved allegations that corridors may be bad for people. Hence, the establishment of the Khata corridor has been a successful conservation initiative.

\section{Tigers and prey}

Although tigers were encountered in the corridor area occasionally before conservation measures were initiated (Bardia 
TABLE 3 Relative frequency of occurrence (\%) of prey species in 127 tiger scats collected in the south-west corner of Bardia National Park and in the Khata corridor (Fig. 1) during winter and summer in 2013.

\begin{tabular}{|c|c|c|c|c|}
\hline \multirow[b]{2}{*}{ Prey species } & \multicolumn{2}{|c|}{ South-west Bardia National Park } & \multicolumn{2}{|l|}{ Khata corridor } \\
\hline & Winter $(\mathrm{n}=59)$ & Summer $(n=26)$ & Winter $(\mathrm{n}=34)$ & Summer $(n=8)$ \\
\hline Chital Axis axis & 65 & 61 & 55 & 50 \\
\hline Hog deer Axis porcinus & 13 & 11 & 11 & 12 \\
\hline Swamp deer Rucervus duvaucelii & 7 & 7 & 0 & 0 \\
\hline Sambar Rusa unicolor & 2 & 3 & 4 & 0 \\
\hline Wild boar Sus scrofa & 9 & 3 & 9 & 0 \\
\hline Barking deer Muntiacus muntjak & 3 & 11 & 5 & 12 \\
\hline Langur Semnopithecus hector & 1 & 4 & 5 & 13 \\
\hline Cattle & 0 & 0 & 11 & 13 \\
\hline
\end{tabular}

TABLE 4 Estimated relative biomass and relative number of prey consumed by tigers in the combined area of the south-west corner of Bardia National Park and the Khata corridor (Fig. 1) during November 2012-August 2013.

\begin{tabular}{|c|c|c|c|c|c|c|}
\hline Prey species & $\begin{array}{l}\text { No of } \\
\text { scats }\end{array}$ & $\begin{array}{l}\text { (A) Frequency of } \\
\text { occurrence }(\%)\end{array}$ & $\begin{array}{l}\text { (B) Body } \\
\text { weight }(\mathrm{kg})\end{array}$ & $\begin{array}{l}\text { (C) Correction factor } \\
\text { (kg of prey per scat) }\end{array}$ & $\begin{array}{l}\text { (D) Relative biomass } \\
\text { consumed }(\%)^{1}\end{array}$ & $\begin{array}{l}\text { (E) Relative no. of indi- } \\
\text { viduals consumed }(\%)^{2}\end{array}$ \\
\hline Chital & 77 & 60.6 & 53 & 3.84 & 57.3 & 51.9 \\
\hline Hog deer & 15 & 12 & 33 & 3.14 & 9.3 & 13.5 \\
\hline Swamp deer & 6 & 4.7 & 159 & 7.55 & 8.7 & 2.6 \\
\hline Sambar & 3 & 2.6 & 212 & 9.4 & 6.0 & 1.4 \\
\hline Wild boar & 9 & 7.2 & 38 & 3.31 & 5.8 & 7.4 \\
\hline Barking deer & 7 & 5.7 & 18 & 2.61 & 3.7 & 9.8 \\
\hline Langur & 5 & 3.4 & 8 & 2.26 & 1.9 & 11.3 \\
\hline Cattle & 5 & 3.8 & 167 & 7.83 & 7.3 & 2.1 \\
\hline Total & 127 & 100 & & & 100 & 100 \\
\hline
\end{tabular}

${ }^{1} \mathrm{D}=(\mathrm{A} \times \mathrm{C}) / \Sigma(\mathrm{A} \times \mathrm{C})$

${ }^{2} \mathrm{E}=(\mathrm{D} / \mathrm{B}) / \Sigma(\mathrm{D} / \mathrm{B})$

TABLE 5 Observed and expected selection among wild prey by tigers in the south-west corner of Bardia National Park and the adjacent Khata corridor (Fig. 1) during November 2012-August 2013 based on likelihood ratio tests and SCATMAN outputs (Link \& Karanth, 1994).

\begin{tabular}{lllrr}
\hline Species & Observed (\%) $\mathbf{x}$ & No. of individuals $\mathrm{km}^{-2}$ & Expected (\%) & $\chi^{2}$ \\
\hline Chital & 64.6 & $47.6(10.9)$ & 79.6 & 8.11 \\
Hog deer & 10.9 & $16.2(4.2)$ & 12.1 & $\mathbf{0}$ \\
Wild boar & 9.6 & $5.7(3.2)$ & 3.7 & $0.171-$ \\
Swamp deer & 5.0 & $2.2(0.9)$ & 2.2 & 14.01 \\
Sambar & 2.5 & $0.2(0.1)$ & 0.2 & 6.87 \\
Barking deer & 5.8 & $0.9(0.4)$ & 2.6 & $\mathbf{0 . 0 0 1 +}$ \\
Primates & 1.6 & $6.3(3.9)$ & 3.2 & $\mathbf{0 . 0 0 9 +}$ \\
\hline
\end{tabular}

${ }^{*}+$ and - indicate preference and avoidance, respectively; bold font indicates statistical significance

National Park staff, pers. comm.), their abundance has increased since then. Resident, breeding tigers were recorded there after the corridor was officially designated as a protected forest. Most of the nine individuals that were recorded in the corridor were also photographed in the south-west corner of Bardia National Park or in Katarniaghat Wildlife Sanctuary, either in the same or the following year. Furthermore, the ranges of tigers that mainly occupied the protected areas extended into the corridor. There was evidence of young tigers dispersing from the Khata corridor to the wildlife sanctuary and from the south-west corner of the park to Khata. Although we found no evidence of tigers moving through the corridor from one protected area to the other, the sampling design and short time interval probably masked such movement; one young tigress that was photographed in the corridor was not recorded again. She could have moved to the wildlife sanctuary.

Twelve females and seven males were identified in total in the study areas, which is a normal sex ratio for this species (Sunquist, 1981). The 2013 density estimate of seven tigers 


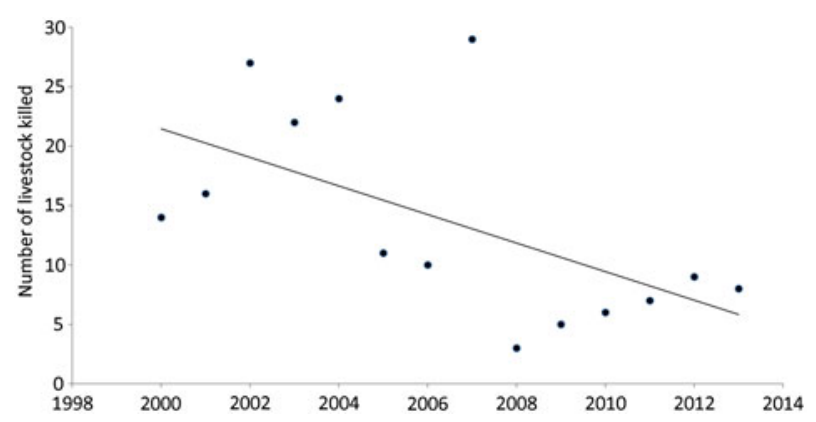

Fig. 3 Yearly records of livestock killed by tigers Panthera tigris in the Khata corridor during 2000-2013.

per $100 \mathrm{~km}^{2}$ for the combined area reflected a relatively dense total population (Jhala et al., 2011). Most recruitment to the corridor was from the south-west of the park, where a high density of tigers $\left(>_{15}\right.$ per $\left.100 \mathrm{~km}^{2}\right)$ was recorded about a decade earlier (Wegge et al., 2009). The increase in tiger numbers in the corridor is probably attributable to a slight increase in the natural prey base and reduced human disturbance as a result of the imposed management interventions.

Wild prey was more than twice as abundant in the southwest corner of the park than in the corridor, the difference being mainly attributable to the presence of $c$. four times more chital, which was not selectively depredated but was the most important food species. Among other important wild food species, only the wild boar was equally abundant in the two areas; sambar and swamp deer were recorded at relatively low frequencies and only in the south-west corner of the park. Large livestock were a supplementary food source in the corridor, accounting for $>10 \%$ of the biomass in the diet of tigers there. Since 2014 grazing in the corridor has been prohibited, except for shorter periods in a few designated patches. Tigers in the corridor are expected to prey more on wild ungulates, thus controlling their population growth, which is an important objective of the habitat improvement activities.

\section{Tiger-human conflict}

In spite of increasing numbers of tigers there was no escalation in conflict with local people. On the contrary, predation of livestock as well as the frequency of attacks on people decreased. A previous study in Bardia National Park and its buffer zone (Bhattarai \& Fischer, 2014) reported a six times higher frequency of fatal encounters and nearly seven times more losses of livestock than were recorded within and along the Khata corridor ( 0.93 and 0.15 people per year, and 2 and $<0.3 \%$ annual loss, respectively). Although the two areas cannot be compared directly, the reason for the relatively low frequencies of human and livestock fatalities as a result of encounters with tigers in the corridor is difficult to explain. In their study Bhattarai \& Fischer (2014) found that livestock losses were higher in areas with low abundance of wild prey, a general conclusion reported from studies elsewhere (Ramakrishnan et al., 1999, Inskip \& Zimmermann, 2009; Goodrich, 2010, but see Suryawanshi et al., 2013). Although data were not available to compare the abundance of wild prey in the corridor and in the park buffer zones, it is unlikely that the natural prey base was higher in Khata. Nor is it likely that there were more tigers in the buffer zone of the park. The lower and declining rate of attacks on people and livestock in the corridor is probably attributable to less human activity and more efficient herding practices there than along the park boundary.

As reported in interviews with residents in the vicinity of the park (Bhattarai \& Fischer, 2014), and in other tigerhuman conflict studies (Gurung et al., 2008; Karanth \& Nepal, 2012), most people in and along the corridor had a positive attitude towards tigers and tiger conservation. Means to reduce livestock loss, and a speedier and better compensation scheme were their highest priorities for reducing local conflicts. These concerns have been addressed by stall feeding and altered grazing regulations and by modifying the process of compensating for loss of livestock and injuries or death inflicted on humans.

The overall positive perception was surprising considering the strict regulations imposed on resource extraction and livestock grazing. The responses to the questionnaires and interviews might have been biased to some extent, as they were carried out by people associated with local conservation institutions. Nevertheless, the positive attitudes were a result of the community development activities being conducted in the corridor, as verified by informal conversations. Securing funding for such activities is facilitated by the concern for tiger conservation within the international community, and it is unlikely that a similar range of activities could have been initiated with the same level of funding if the area had not been identified and designated as a tiger corridor. As such, the Khata corridor exemplifies the system of payment for ecosystem services (Jack et al., 2008) and the wildlife premium mechanism (Dinerstein et al., 2013).

\section{Future of the Khata corridor}

Although the establishment of the corridor has been a success for tiger conservation and has been accepted by local residents, it faces threats from development and from two large-scale irrigation projects that are expected to reduce water flow in the floodplain, which would affect the ecosystem along the western part of the park and the corridor. Attempts are being made to minimize negative effects on tigers and other biodiversity.

Management of the corridor is being modified continually to ease the conflict with local residents while simultaneously improving the quality of tiger habitat. Both resident 
TABLE 6 The perceptions of local people $(n=170)$ in and along the border of the Khata corridor (Fig. 1) regarding tigers and tiger conservation, based on responses to a household survey.

\begin{tabular}{lr}
\hline & $\%$ responses \\
\hline Respondents with positive attitudes towards tigers & 68 \\
Because: & 39 \\
They provide revenue \& jobs in ecotourism. & 27 \\
They have ecological value for a healthy ecosystem. & 21 \\
They are threatened \& declining. & 11 \\
They are beautiful \& charismatic. & 2 \\
They have religious value/are a symbol of might. & 32 \\
Respondents with negative attitudes towards tigers & \\
Because: & 65 \\
They kill livestock. & 35 \\
They attack people. & \\
Attitudes towards tiger conservation & 56 \\
Against if family member lost or injured & 67 \\
Positive if own livestock killed & 45 \\
Capture problem tigers \& kill or put in zoo & 35 \\
Provide conservation education & 15 \\
Better compensation to victims/family & 5 \\
Monitoring of problem tigers & 67 \\
Why tigers were being killed & 21 \\
For trade in body parts & 12 \\
Retaliation for livestock killing & 26 \\
Reduce risk of attacks on people/livestock & \\
Easier to kill livestock & \\
\hline
\end{tabular}

and transient tigers are likely to increase in number with the availability of more natural prey and less human disturbance. During a transition period, while the wild prey is increasing and more dispersing tigers immigrate from the park, conflicts may escalate rather than diminish. Only when, and if, the natural prey base becomes sufficiently abundant to sustain the number of tigers occupying and frequenting the corridor is the level of conflict likely to diminish. Tiger-human conflict is likely to persist at the current, low level. Hence, the conservation effort has been a success; connectivity between Bardia National Park and Katarniaghat Wildlife Sanctuary supports the maintenance of genetic viability in the tiger populations, and the critical concern that corridors may be bad for people has been refuted. Furthermore, by linking the two protected areas via the Khata corridor, a large, functional tiger landscape, consisting of a c. $200-\mathrm{km}$-long arc of contiguous protected areas (Katarniaghat Wildlife Sanctuary, Khata corridor, Bardia and Banke National Parks and their buffer zones, Kamdi corridor and Suhelwa Wildlife Sanctuary) covering an area of c. 3,000 $\mathrm{km}^{2}$, with $>8$ o adult tigers, has been securely established in the transboundary Terai Arc Landscape in west-central Nepal.

\section{Acknowledgements}

We thank the Department of National Parks and Wildlife Conservation, Nepal for permission and support for carrying out this study. Funding was provided by the USAID Hariyo Ban Program, managed by WWF Nepal, and by the National Trust for Nature Conservation (NTNC). NTNC and Bardia National Park provided logistical and technical assistance. We are grateful to Hemanta K. Yadav for assistance with analysing the prey data, and to Shant R. Jnawali, Khadga B. Basnet and Naresh Subedi for encouragement and general research support.

\section{Author contributions}

PW designed the study, assisted in the statistical analyses and wrote the article. SKY implemented the study in the field, analysed the photographs and scats, and did the preliminary statistical analyses. BRL carried out the statistical modelling of the tiger data and assisted in writing the manuscript.

\section{References}

Ackerman, B.B., Lindzey, F.G. \& Hemker, T.P. (1984) Cougar food habits in southern Utah. The Journal of Wildlife Management, 48, 147-155.

Athreya, V., Navya, R., Punjabi, G.A., Linnell, J.D.C., Odden, M., Khetarpal, S. \& Karanth, K.U. (2014) Movement and activity pattern of a collared tigress in a human-dominated landscape in central India. Tropical Conservation Science, 7, 75-86. 
Bhattarai, B.R. \& Fischer, K. (2014) Human-tiger Panthera tigris conflict and its perception in Bardia National Park, Nepal. Oryx, 48, 522-528.

Biswas, S. \& Sankar, K. (2002) Prey abundance and food habit of tigers (Panthera tigris tigris) in Pench National Park, Madhya Pradesh, India. Journal of Zoology, 256, 411-420.

Bolton, M. (1976) Royal Karnali Wildlife Reserve Managment Plan, 1976-1981. FAO/NEP/Project document 72/oo2. FAO, Rome, Italy.

Buckland, S.T., Anderson, D.R., Burnham, K.P., LaAke, J.L., Borchers, D.L. \& Thomas, L. (2001) Introduction to Distance Sampling. Oxford University Press, Oxford, UK.

Carbone, C., Christie, S., Conforti, K., Coulson, T., Franklin, N., GinsberG, J.R. et al. (2001) The use of photographic rates to estimate densities of tigers and other cryptic mammals. Animal Conservation, 4, 75-79.

Chanchani, P., Lamichinane, B.R., Malla, S., Maurya, K., Bista, A., Warrier, R. et al. (2014) Tigers of the Transboundary Terai Arc Landscape: Status, Distribution and Movement in the Terai of India and Nepal. National Tiger Conservation Authority, Government of India, and the Department of National Parks and Wildlife Conservation, Government of Nepal.

Ciucci, P., Tosoni, E. \& Boitani, L. (2004) Assessment of the point-frame method to quantify wolf Canis lupus diet by scat analysis. Wildlife Biology, 10, 149-153.

Dhakal, M., Karki, M., Jnawali, S.R., Subedi, N., Pradhan, N.M.B., Malla, S. et al. (2014) Status of Tigers and Prey in Nepal. Department of National Parks and Wildlife Conservation, Kathmandu, Nepal.

Dinerstein, E. (1979) An ecological survey of the Royal Karnali-Bardia Wildlife Reserve, Nepal. Part I: vegetation, modifying factors, and successional relationships. Biological Conservation, 15, 127-150.

Dinerstein, E., Loucks, C., Heydlauff, A., Wikramanayake, E., Bryja, G., Forrest, J. et al. (2006) Setting Priorities for the Conservation and Recovery of Wild Tigers: 2005-20015. A User's Guide. WWF, WCS, Smithsonian \& NFWF-STF, Washington, DC \& New York, USA.

Dinerstein, E., Varma, K., Wikramanayake, E., Powell, G., Lumpkin, S., Naidoo, R. et al. (2013) Enhancing conservation, ecosystem services, and local livelihoods through a wildlife premium mechanism. Conservation Biology, 27, 14-23.

Farrell, L.E., Roman, J. \& Sunquist, M.E. (200o) Dietary separation of sympatric carnivores identified by molecular analysis of scats. Molecular Ecology, 9, 1583-1590.

Goodrich, J.M. (2010) Human-tiger conflict: a review and call for comprehensive plans. Integrative Zoology, 5, 300-312.

Gopalaswamy, A.M., Royle, J.A., Hines, J.E., Singh, P., Jathanna, D., Kumar, N.S. \& Karanth, K.U. (2012) Program SPACECAP: software for estimating animal density using spatially explicit capture-recapture models. Methods in Ecology and Evolution, 3, 1067-1072.

GTrP (Global Tiger Recovery Program) (2010) The St. Petersburg Declaration on Tiger Conservation. Http://www. globaltigerinitiative.org/download/St_Petersburg/St_Petersburg Declaration_English.pdf [accessed 4 August 2016].

Gurung, B., Smith, J.L.D., McDougal, C., Karki, J.B. \& Barlow, A. (2008) Factors associated with human-killing tigers in Chitwan National Park, Nepal. Biological Conservation, 141, 3069-3078.

Harihar, A. \& PANDAv, B. (2012) Influence of connectivity, wild prey and disturbance on occupancy of tigers in the human-dominated western Terai Arc Landscape. PLoS ONE, 7(7), e40105.

Inskip, C. \& Zimmermann, A. (2009) Human-felid conflict: a review of patterns and priorities worldwide. Oryx, 43, 18-34.
Jack, B.K., Kousky, C. \& Sims, K.R.E. (2008) Designing payments for ecosystem services: lessons from previous experience with incentive-based mechanisms. PNAS, 105, 9465-9470.

Jhala, Y.V., Quereshi, Q., Gopal, R. \& Sinha, P.R. (eds) (2011) Status of Tigers, Co-predators and Prey in India, 2010. Technical Report. National Tiger Conservation Authority, Government of India, New Delhi, and Wildlife Institute of India, Dehradun, India.

Jnawali, S.R. (1995) Population ecology of greater one-horned rhinoceros (Rhinoceros unicornis) with particular emphasis on habitat preference, food ecology and ranging behaviour of a reintroduced population in Royal Bardia National Park in lowland Nepal. PhD thesis. Agricultural University of Norway, Ås, Norway.

Joshi, A., Vaidyanathan, S., Mondol, S., Edgaonkar, A. \& Ramakhrishnan, U. (2013) Connectivity of tiger (Panthera tigris) populations in the human-influenced forest mosaic of central India. PLOS ONE, 8(11), e77980.

Karanth, K.K. \& NePal, S.K. (2012) Local residents' perception of benefits and losses from protected areas in India and Nepal. Environmental Management, 49, 372-386.

Karanth, K.U. (1995) Estimating tiger Panthera tigris populations from camera-trap data using capture-recapture models. Biological Conservation, 71, 333-338.

Karanth, K.U. \& Nichols, J.D. (1998) Estimation of tiger densities in India using photographic captures and recaptures. Ecology, 79, 2852-2862.

Karanth, K.U. \& Stith, B.M. (1999) Prey depletion as a critical determinant of tiger population viability. In Riding the Tiger: Tiger Conservation in Human-Dominated Landscapes (eds J. Seidensticker, S. Christie \& P. Jackson), pp. 100-113. Cambridge University Press, Cambridge, UK.

Karanth, K.U. \& Sunquist, M.E. (1995) Prey selection by tiger, leopard and dhole in tropical forests. Journal of Animal Ecology, 64, 439-450.

Kenney, J., Allendorf, F.W., McDougal, C. \& Smith, J.L.D. (2014) How much gene flow is needed to avoid inbreeding depression in wild tiger populations? Proceedings of the Royal Society of London B: Biological Sciences, 281, 20133337.

LinK, W.A. \& KARANTH, K.U. (1994) Correcting for overdispersion in tests of prey selectivity. Ecology, 75, 2456-2459.

Mukherjee, S., Goyal, S.P. \& Chellam, R. (1994) Standardisation of scat analysis techniques for leopard Panthera pardus in Gir National Park, Western India. Mammalia, 58, 139-144.

Nowell, K. \& Jackson, P. (1996) Wild Cats: Status Survey and Conservation Action Plan. IUCN, Gland, Switzerland.

Otis, D.L., Burnham, K.P., White, G.C. \& Anderson, D.R. (1978) Statistical inference from capture data on closed animal populations. Wildlife Monographs, 62, 1-135.

R Development Core Team (2013) R: A Language and Environment for Statistical Computing. R Foundation for Statistical Computing, Vienna, Austria.

Ramakrishnan, U., Coss, R.G. \& Pelkey, N.W. (1999) Tiger decline caused by the reduction of large ungulate prey: evidence from a study of leopard diets in southern India. Biological Conservation, 89, 113-120.

Rathore, C.S., Dubey, Y., Shrivastava, A., Pathak, P. \& Patil, V. (2012) Opportunities of habitat connectivity for tiger (Panthera tigris) between Kanha and Pench National Parks in Madhya Pradesh, India. PLoS ONE, 7(7), e39996.

Royle, J.A., Nichols, J.D., Karanth, K.U. \& Gopalaswamy, A.M. (2009) A hierarchical model for estimating density in camera-trap studies. Journal of Applied Ecology, 46, 118-127.

Saberwal, V.K., Gibis, J.P., Chellam, R. \& Johnsingh, A.J.T. (1994) Lion-human conflict in the Gir forest, India. Conservation Biology, 8, 501-507. 
Sharma, S., Dutta, T., Maldonado, J.E., Wood, T.C., Panwar, H. S. \& SeIdensticker, J. (2013a) Forest corridors maintain historical gene flow in a tiger metapopulation in the highlands of central India. Proceedings of the Royal Society of London B: Biological Sciences, 280, 20131506.

Sharma, S., Dutta, T., Maldonado, J.E., Wood, T.C., Panwar, H. S. \& Seidensticker, J. (2013b) Spatial genetic analysis reveals high connectivity of tiger (Panthera tigris) populations in the Satpura-Maikal landscape of Central India. Ecology and Evolution, 3, 48-60.

Simberloff, D., Farr, J.A., Cox, J. \& Mehlman, D.W. (1992) Movement corridors: conservation bargains or poor investments? Conservation Biology, 6, 493-504.

Smith, J.L.D., Ahearn, S.C. \& McDougal, C. (1998) Landscape analysis of tiger distribution and habitat quality in Nepal. Conservation Biology, 12, 1338-1346.

Sunquist, M.E. (1981) The social organization of tigers in Royal Chitawan National Park, Nepal. Smithsonian Contributions to Zoology, 336, 1-98.

Suryawanshi, K.R., Bhatnagar, Y.V., Redpath, S. \& Mishra, C. (2013) People, predators and perceptions: patterns of livestock depredation by snow leopards and wolves. Journal of Applied. Ecology, 50, 550-560.

Thomas, L., Buckland, S.T., Rexstad, E.A., Laake, J.L., Strindierg, S., Hedley, S.L. et al. (2010) Distance software: design and analysis of distance sampling surveys for estimating population size. Journal of Applied Ecology, 47, 5-14.

Thomas, L., LaAke, J.L., Rextad, E., Strind berg, S., Marques, F.F. C., Buckland, S.T. et al. (2009) Distance 6.o. Release 2. University of St. Andrews, UK.

Treves, A. \& Karanth, K.U. (2003) Human-carnivore conflict and perspectives on carnivore management worldwide. Conservation Biology, 17, 1491-1499.

Wegge, P., Odden, M., Pokharel, C.P. \& Storaas, T. (2009) Predator-prey relationships and responses of ungulates and their predators to the establishment of protected areas: a case study of tigers, leopards and their prey in Bardia National Park, Nepal. Biological Conservation, 142, 189-202.

Wegge, P., Pokharel, C.P. \& Jnawali, S.R. (2004) Effects of trapping effort and trap shyness on estimates of tiger abundance from camera trap studies. Animal Conservation, 7, 251-256.

Wegge, P., Shrestha, R. \& Flagstad, Ø. (2012) Snow leopard Panthera uncia predation on livestock and wild prey in a mountain valley in northern Nepal: implications for conservation management. Wildlife Biology, 18, 131-141.

Wegge, P. \& Storaas, T. (2009) Sampling tiger ungulate prey by the distance method: lessons learned in Bardia National Park, Nepal. Animal Conservation, 12, 78-84.

White, G.C., Burnham, K.P., Otis, D.L. \& Anderson, D.R. (1978) Users' Manual for Program CAPTURE. Utah State University Press, Utah, USA.

Wikramanayake, E., Dinerstein, E., Robinson, J.G., Karanth, K.U., Rabinowitz, A., Olson, D. et al. (1998) An ecology-based method for defining priorities for large mammal conservation: the tiger as case study. Conservation Biology, 12, 865-878.

Wikramanayake, E., McKnight, M., Dinerstein, E., Joshi, A., Gurung, B. \& S Sith, D. (2004) Designing a conservation landscape for tigers in human-dominated environments. Conservation Biology, 18, 839-844.

Woodroffe, R., Thirgood, S. \& Rabinowitz, A. (eds) (2005) People and Wildlife: Conflict or Coexistence? Cambridge University Press, Cambridge, UK.

Yumnam, B., Jhala, Y.V., Quereshi, Q., Maldonado, J.E., Gopal, R., SAINI, S. et al. (2014) Prioritizing tiger conservation through landscape genetics and habitat linkages. PLoS ONE, 9(11), e111207.

ZAR, J.H. (1984) Biostatistical Analysis. Prentice Hall, Upper Saddle River, USA.

\section{Biographical sketches}

PER WegGe has studied the habitat, food ecology and predator-prey relationships of large mammals in Nepal for more than 20 years. Shailendra Kumar Yadav monitors the abundance of large mammals within and outside protected areas in the lowland Terai region. BABU RAM LAMICHHANE models the structure and density of tiger and leopard populations, with a recent focus on human-wildlife interactions. 